\title{
THE INTERMEDIATE PYROLYSIS OF DE-INKING SLUDGE TO PRODUCE A SUSTAINABLE LIQUID FUEL
}

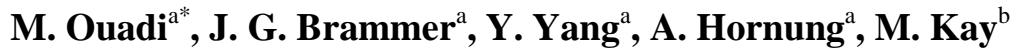 \\ ${ }^{a}$ European Bio-energy Research Institute (EBRI), \\ Aston University, Birmingham, UK \\ ${ }^{\mathrm{b}}$ Smithers Pira, Leatherhead, Surrey, UK \\ ouadim@aston.ac.uk, j.g.brammer@aston.ac.uk,y.yang6@aston.ac.uk \\ a.hornung@aston.ac.uk,mkay@smithers.com
}

\begin{abstract}
De-inking sludge is a waste product generated from secondary fibre paper mills who manufacture recycled paper into new paper sheets; it refers directly to the solid residues which evolve during the de-inking stage of the paper pulping process. The current practice for the disposal of this waste is either by landspreading, landfilling or incineration which is unsustainable. This work has explored the intermediate pyrolysis of pre-conditioned de-inking sludge pellets in a recently patented $20 \mathrm{~kg} / \mathrm{h}$ intermediate pyrolysis reactor (The Pyroformer). The reactor is essentially two auger screws which are configured in such a way as to circulate solids within the reactor and thus facilitate in the cracking of tars. The potential application of using the volatile organic vapours and permanent gases evolved would be to generate both combined heat and power (CHP) located at paper making sites. The results show that de-inking sludge could be successfully pyrolysed and the organic vapours produced was largely composed of phenolic compounds and some fatty acid methyl esters as detected by liquid GCMS. The calorific value of the oil after condensing was between $36-37 \mathrm{MJ} / \mathrm{kg}$ and the liquid fuel properties were also determined, permanent gases were detected by a GC-TCD and was composed of approximately $24 \% \mathrm{CO}, 6 \% \mathrm{CH}_{4}$ and $70 \% \mathrm{CO}_{2}(\mathrm{v} / \mathrm{v} \%)$. After pyrolysis the solid char residue also contained a small residual calorific value, and was largely composed of mainly calcium based inert metal oxides. The application of applying intermediate pyrolysis to de-inking sludge for both CHP production and waste reduction is in principle a feasible technology which could be applied at secondary fibre paper making sites.
\end{abstract}

Keywords: Pyrolysis, CHP, De-inking Sludge, Waste

*Corresponding author; (M. Ouadi), Email; ouadim@aston.ac.uk, Tel; +44 (0) 121204 3088, Aston University, Aston Triangle, Birmingham, UK, B4 7ET

\begin{tabular}{ll} 
Abbreviations: & \\
\hline CHP & Combined Heat and Power \\
AN & Aylesford Newsprint Ltd \\
KC & Kimberly Clark Flint \\
TGA & Thermo Gravimetric Analysis \\
HHV & Gross Heating Value \\
GC-MS & Gas Chromatography Mass Spectrometry \\
GC-TCD & Gas Chromatograph Thermal Conductivity Detector \\
\hline
\end{tabular}




\subsection{INTRODUCTION}

The production of combined heat and power (CHP) based on the pyrolysis of biomass and wastes is a growing technology, which can be applied to reduce the demand for fossil fuels and thereby contribute to the reduction of greenhouse gas emissions.

Pyrolysis is defined as the thermal decomposition of organic matter in the complete absence of oxygen, and intermediate pyrolysis is characterised by moderate residence times of 1-15 minutes and reaction temperatures of $400-550{ }^{\circ} \mathrm{C}$. Intermediate pyrolysis produces large quantities of condensable organic vapours with a calorific content. These can be combusted in the vapour phase to raise steam for CHP generation. Alternatively they can be condensed to form pyrolysis oil, also known as bio-oil [1], with the advantages of handling and storage associated with liquid fuels compared with gaseous and solid fuels. The bio-oil can be used in a modified diesel engine or further upgraded or blended for use in conventional engines [2]. Intermediate pyrolysis also generates moderate amounts of permanent combustible gases, and also relatively large quantities of char which can itself be used as a solid fuel or alternatively returned to the soil as a "bio-char" for carbon sequestration and soil conditioning [1].

This paper focuses on the pyrolysis of wastes derived from the pulp and paper industry, in particular from secondary (recycled) fibre mills which generate significant tonnages of de-inking sludge (mainly inks, dyes, fibres and inorganic fillers). This waste fraction evolves during the deinking stage of recycled paper manufacture, and can contain significant amounts of useful energy. Approximately 1 million tonnes of de-inking sludge is produced in the UK each year [3], and much of this is disposed of by landfilling or land-spreading, both of which are becoming increasingly problematical practices.

Secondary fibre paper mills are also significant users of energy in the form of both electricity and heat to power machinery and to dry paper sheets. As the cost for producing this energy increases year upon year, many UK based mills are finding it increasingly difficult to remain profitable, and this has led to the closure of lower tonnage operations that manufacture commodity grade paper and board products [4]. In order to raise part of the energy they require, some paper mills burn de-inking sludge in a combustor and use the heat in the exhaust gases to raise steam for use either directly in the mill or in a steam turbine for CHP. However the sludge has far too little calorific content to be combusted without the need for large quantities of co-fired natural gas, which is both non-renewable and expensive. The use of pyrolysis as an alternative route to energy has the potential to significantly increase the amount of sludge used for energy recovery, and in the process substantially reduce or eliminate the requirement for natural gas.

Little work has been carried out to date on the pyrolysis of this material [5]. In one study carried out by Lou .R et al [6], TGA, PY-GCMS and bench scale pyrolysis of de-inking sludge was performed at $400^{\circ} \mathrm{C}$ and $800^{\circ} \mathrm{C}$ in order to evaluate the use of de-inking sludge as a fuel. The results showed that as much as $24 \mathrm{wt} \%$ bio oil could be produced, together with a gas composed mainly of $\mathrm{CO}, \mathrm{H}_{2}$ and $\mathrm{CH}_{4}$. It was concluded that using de-inking sludge pyrolysis products as a fuel was feasible although further research into this area was necessary for future development.

In the present work, dried and pelletised de-inking sludge is processed in a recently patented 20 $\mathrm{kg} / \mathrm{h}$ intermediate pyrolysis reactor (the Pyroformer [7]), with the objective of quantifying and characterising the products formed and assessing the feasibility of implementing such a process for CHP generation at secondary fibre paper mill sites. Details are presented of the pre-treatment and characterisation of de-inking sludge to determine the proximate and ultimate compositions and energy content; the intermediate pyrolysis experiments themselves; and the full characterisation of the products formed. 


\subsection{MATERIALS AND METHODS}

\subsection{Raw Materials}

Secondary fibre paper mills use recovered paper fibre to manufacture new paper sheets, and de-inking sludge is a solid waste residue generated during the de-inking stage of this process. Waste paper contains a large fraction of inorganic substances including printing and writing inks, dyes, and fillers such as kaolin $\left(\mathrm{Al}_{2} \mathrm{O}_{3}, \mathrm{SiO}_{2}, \mathrm{H}_{2} \mathrm{O}\right)$, talc $\left(\mathrm{Mg}_{3} \mathrm{Si}_{4} \mathrm{O}_{10}(\mathrm{OH})_{2}\right)$, calcium carbonate $\left(\mathrm{CaCO}_{3}\right)$, and clays that are added to improve printability, smoothness, opacity and appearance of the finished paper product. De-inking sludge comprises the fillers, inks, pigments, fibres and fibre fines and adhesives that are removed from the initial paper feedstock. This is done by mechanical agitation, with dissolved air flotation and the use of alkali and surface active reagents, and the de-inking sludge is skimmed off the surface. It has a high moisture content which is reduced down to $35-40 \mathrm{wt} \%$ by de-watering, a high ash content of 40-60 wt\% (dry basis) which is mainly calcium carbonate, and a low calorific value of 6-7 MJ/kg (HHV dry basis) [5]. The very high ash content along with the very low calorific value makes the use of this waste as a fuel extremely challenging.

In order to take into account the variability of de-inking sludge from mill to mill, material was acquired from both a mill which manufactures tissue products (Kimberly Clark Flint - KC) and a mill which manufactures newsprint (Aylesford Newsprint - AN).

\subsection{Feedstock Pre-treatment}

Before pyrolysis the de-inking sludge required some pre-treatment. For intermediate pyrolysis, the feed needed to be as dry as possible, and also the Pyroformer unit requires a pelletised feed to ensure blockage-free operation. Approximately $700 \mathrm{Kg}$ of wet de-inking sludge was received from both the (AN) and (KC) mills. The feedstock as received contained an average moisture content of approximately $35-40 \mathrm{wt} \%$. This was dried to a moisture content of $<3 \mathrm{wt} \%$ by an external company Drymatter Ltd. using an industrial scale rotary drum drier at a drying temperature of $1000{ }^{\circ} \mathrm{C}$. The dry granular material was then pelletised using a roll and die 9PK-200 (7.5 kWe) motorised pelletiser with total capacity of $100-150 \mathrm{~kg} / \mathrm{hr}$ throughput. The pellets formed were of dimensions $6 \mathrm{~mm}$ diameter by $15 \mathrm{~mm}$ length (Figure 1).

\subsection{Feedstock Characterisation}

Prior to pelletising, the dried de-inking sludge was analysed in order to determine the proximate, ultimate compositions and gross heating value.

\subsubsection{Proximate Analysis}

Proximate analysis determines the moisture, volatiles, fixed carbon and ash present. This was carried out by Thermo Gravimetric Analysis (TGA) in a Perkin Elmer Pyris 1 TGA device with auto sampler. To determine the moisture, volatiles and combined fixed carbon and ash, approximately $5 \mathrm{mg}$ of dried de-inking sludge is loaded into a tarred crucible and pyrolysis of the sample was carried out under an inert atmosphere of $\mathrm{N}_{2}$ with the following temperature programme:

- Heating from ambient to $50{ }^{\circ} \mathrm{C}$ at heating rate $5{ }^{\circ} \mathrm{C} / \mathrm{min}$

- Hold for 5 minutes at $50{ }^{\circ} \mathrm{C}$

- Heating from $50{ }^{\circ} \mathrm{C}$ to $105^{\circ} \mathrm{C}$ at heating rate $5{ }^{\circ} \mathrm{C} / \mathrm{min}$

- Hold for 5 minutes at $105^{\circ} \mathrm{C}$

- Heating from $105^{\circ} \mathrm{C}$ to $900{ }^{\circ} \mathrm{C}$ at heating rate $25^{\circ} \mathrm{C} / \mathrm{min}$

- Hold for 15 minutes at $900{ }^{\circ} \mathrm{C}$ 
- Cooling to ambient at cooling rate $25^{\circ} \mathrm{C} / \mathrm{min}$

The moisture content is determined after holding at $105{ }^{\circ} \mathrm{C}$, the total char is determined after cooling, and the volatile content is obtained by difference. To determine the ash content, the same programme is used but in an atmosphere of air so that the fixed carbon in the char is combusted.

\subsubsection{Ultimate Analysis}

Ultimate analysis was carried out by an external company Medac Ltd using a Carlo-Erba EA1108 CHNS-O analyser by total oxidation. Elemental compositions ( $\mathrm{C} \mathrm{H} \mathrm{N} \mathrm{O}, \mathrm{S}$, and $\mathrm{Cl}$ ) are obtained on a dry basis.

\subsubsection{Gross Heating Value (HHV)}

The gross heating value in $(\mathrm{MJ} / \mathrm{Kg})$ of all samples was determined using a Parr 6100 bomb calorimeter, and was verified using the unified correlation for fuels developed by Channiwala et al [8]:

$$
\mathrm{HHV}(\mathrm{MJ} / \mathrm{kg})=0.3491(\mathrm{C})+1.1783(\mathrm{H})+0.1005(\mathrm{~S})-0.1034(\mathrm{O})-0.0151(\mathrm{~N})-0.0211(\mathrm{~A})
$$

\subsection{Intermediate Pyrolysis Experiments}

The Pyroformer laboratory-scale intermediate pyrolysis reactor [7] was originally manufactured in Germany before being installed and commissioned at the European Bioenergy Research Institute (EBRI) at Aston University. The installation is shown in Figure 2.

The Pyroformer (Figure 3) is essentially an auger pyrolysis reactor with two counter-rotating coaxial screws which can process a feed in an inert atmosphere of nitrogen at a rate of up to $20 \mathrm{~kg} / \mathrm{hr}$. The reactor is heated externally by electrical heating bands and the feed moves through the screw conveyor system whilst being heated to the specified pyrolysis temperature. Some solid residue (char and ash) is recycled within the reactor, the remainder drops out at the downstream end of the reactor, and the pyrolysis vapours and gases exit through an outlet pipe. The recycling of char increases the char to feedstock ratio in the reaction zone which promotes catalytic cracking of the primary vapours to lower molecular weight vapours and permanent gases. It also serves to recycle heat within the reactor and increase the heating rate experienced by the feedstock. The design is well suited to deinking sludge as it can process feeds with very high ash contents.

The Pyroformer is initially heated to its set point temperature of $450{ }^{\circ} \mathrm{C}$. Then, after purging with $\mathrm{N}_{2}$, the unit is fed with pelletised feedstock at a rate of approximately $15 \mathrm{~kg} / \mathrm{hr}$ from a feed hopper. A steady state is established after approximately 60 minutes. For removal of entrained solid particulates the hot organic vapours and permanent gases are first passed through hot gas filter candles which are also maintained at $450{ }^{\circ} \mathrm{C}$. Then the vapours and gases are routed to a shell and tube water cooled condenser where the great majority of the pyrolysis vapours are condensed. Any remaining vapours and the permanent gases are then passed to an electrostatic precipitator for aerosol knock out and then to a GC-TCD for detection. Approximately 3 litres of pyrolysis oil is collected from each run. A schematic of the process is shown in Figure 4.

\subsection{Pyrolysis Products Analysis}

After the production of pyrolysis oil, gases and solids were characterised to determine both their physical properties and chemical compositions. 


\subsubsection{Water content}

Water content of all pyrolysis oil samples was determined by a Mettler Toledo V20-Compact volumetric Karl-Fischer titration unit using a Hydranal composite 5K titrant and was carried out in accordance with the ASTM-E203 standard test procedure.

\subsubsection{Kinematic Viscosity}

Kinematic Viscosity of all pyrolysis oil samples was measured by Cannon-Fenske routine viscometer and was measured in accordance with the ASTM-D445 standard test procedure.

\subsubsection{Gross Heating Value}

The gross heating value (HHV) of the pyrolysis oil and char samples was determined using a Parr 6100 bomb calorimeter as previously described in Section 2.3.3.

\subsubsection{Ultimate analysis}

For determination of the elemental compositions ( $\mathrm{C} \mathrm{H} \mathrm{N} \mathrm{O}$ and $\mathrm{S}$ ), samples of the pyrolysis oil and char were analysed externally by Medac Ltd using a Carlo- Erba EA1108 CHNS-O analyser by total oxidation.

\subsubsection{Flashpoint}

Flashpoints of the pyrolysis oil were measured using an automated closed cup FP tester according to ASTM-D93 standard test procedure.

\subsubsection{Density}

The density of the pyrolysis oil was measured at $22^{\circ} \mathrm{C}$ using a glass hydrometer of range $(0.8$ $1.0 \mathrm{gm} / \mathrm{cu} . \mathrm{cm}$ ) according to ASTM-D4809 standard test procedure.

\subsection{7 $\mathrm{pH}$}

$\mathrm{pH}$ of the pyrolysis oil was determined using Fisher-brand $\mathrm{pH}$ meter calibrated with standard buffer solutions according to ASTM-D7544 standard test procedure.

\subsubsection{Acid Number}

Acid number of the pyrolysis oil was measured potentiometrically with an alcoholic potassium hydroxide titrant, using a Mettler Toledo G20 Compact titrator device in accordance with ASTM-66404 standard test procedure.

\subsubsection{Copper Corrosion, ICP-Metals and Cetane Index}

Samples of pyrolysis oil were measured externally by ALcontrol Laboratories Ltd for determination of copper corrosiveness, icp-metals and cetane index.

\subsubsection{Ash Content}

Ash content of the pyrolysis oil was determined in a Carbolite furnace model AAF-1100 in accordance with ASTM-D482-03 standard test procedure. Ash of the solid char was determined by TGA Combustion as previously described in section 2.3.1 of this paper.

\subsubsection{Carbon Residue}

Carbon residue of the pyrolysis oil was determined in accordance with the ASTM-D524-09 standard test procedure. 


\subsubsection{Liquid GCMS}

GC-MS was performed to identify the most abundant compounds present within the pyrolysis oil. Samples of the oil were diluted in ethanol in a 1:10 ratio. GC-MS analysis was conducted using a Hewlett Packard HP 5890 Series II Gas Chromatograph with an automatic injector and auto sampler with a DB 1706 non-polar capillary column of $60 \mathrm{~m} \times 0.25 \mathrm{~mm} \times 0.25 \mu \mathrm{m}$. Helium was used as the carrier gas at a constant flow rate of $1.5 \mathrm{ml} / \mathrm{min}$ The initial oven temperature was $40{ }^{\circ} \mathrm{C}$ and ramped up to $290{ }^{\circ} \mathrm{C}$. Identification of the GC-MS peaks was based on the comparison between the Massfinder library and Wiley library.

\subsubsection{Permanent Gas Analysis}

Permanent gas samples were taken after condensing of the oils and injected into a GC-TCD at every 25 minute intervals. Gas analysis was carried out using a Gas Chromatograph Thermal Conductivity Detector (GC-TCD) in a Hewlett Packard HP-5890 Series II device with a 60/80 Carboxen 1000 column. Oven temperature was pre programmed to an initial temperature of $35^{\circ} \mathrm{C}$ and ramped to 225 ${ }^{\circ} \mathrm{C}$ at a rate of $20^{\circ} \mathrm{C} / \mathrm{min}$ and Helium with a flow rate of $30 \mathrm{ml} / \mathrm{min}$ was used as the carrier gas.

\subsection{RESULTS AND DISCUSSION}

\subsection{Feedstock Characterisation}

Table 1 presents the proximate and ultimate analyses and heating value of the pre-treated de-inking sludge feedstocks from each mill used in intermediate pyrolysis trials. Figure 5-8 shows the TGA pyrolysis and combustion derivative weight loss profiles.

It is observed from Table 1 that both the de-inking sludge from AN mill and KC mill are very similar. They both have a very low calorific value and very high ash content. Further analysis of the composition of de-inking sludge ash revealed that it was composed of largely calcium and aluminium based metal oxides. It may therefore be surmised that de-inking sludge ash would share similar properties to those of dolomite which would make its use as a tar cracking catalyst at elevated temperatures a promising prospect. It has been shown elsewhere [2] that the ash content of de-inking sludge can be reduced before pyrolysis by as much as $65 \%$ by pre-treatment with an acid bath $(\mathrm{HCl}$ and $\mathrm{H}_{2} \mathrm{SO}_{4}$ were both shown to work well). Acid washing pre-treatment of biomass for ash removal is well documented $[9,10,11]$ and its application to pre-treat de-inking sludge is also possible in principle.

The TGA pyrolysis and combustion derivative weight loss profiles for both $\mathrm{KC}$ and AN de-inking sludges are shown in Figures 5-8 and in general the two sludges show similar behaviour, whether exposed either to air or an inert atmosphere of nitrogen. Weight loss is seen between $200{ }^{\circ} \mathrm{C}$ and 450 ${ }^{\circ} \mathrm{C}$, and then again between $700{ }^{\circ} \mathrm{C}$ and $800{ }^{\circ} \mathrm{C}$. The rate of weight loss between $200{ }^{\circ} \mathrm{C}$ and $450{ }^{\circ} \mathrm{C}$ peaks at approximately $350-400{ }^{\circ} \mathrm{C}$, and this is the direct result of the decomposition of the cellulosic fibres and other de-inking minerals. As a result of the increased amount of volatiles present within the $\mathrm{KC}$ de-inking sludge, the rate of weight loss is observed to be higher for $\mathrm{KC}$ sludge (Figure 5) than for AN sludge (Figure 6). The rate of weight loss between $700{ }^{\circ} \mathrm{C}$ and $800{ }^{\circ} \mathrm{C}$ peaks at approximately $800{ }^{\circ} \mathrm{C}$ and this is largely the result of the thermal decomposition of $\mathrm{CaCO}_{3}$ present within the ash. Similar peak rates are observed for the two sludges. Above $900{ }^{\circ} \mathrm{C}$, between $43-52 \%$ of the original dry solid sample is present as inorganic metal oxide compounds, so no further weight loss is experienced. The metals present within both the $\mathrm{KC}$ and $\mathrm{AN}$ ashes were found to be predominantly aluminium and calcium, with other elements in far smaller quantities. 


\subsection{Intermediate Pyrolysis Trials}

\subsubsection{Intermediate Pyrolysis Bio-oil Characterisation}

After condensing of the organic vapours formed from de-inking sludge pyrolysis, the bio-oil was found to be of a high quality with a very high calorific value (close to $40 \mathrm{MJ} / \mathrm{kg}$, comparable to biodiesel) after removal of an easily separated aqueous phase representing about $10 \%$ by weight. The oil was separated from the aqueous phase by gravity settling and was then characterised for its energy content and ultimate compositions; these are presented in Table 2.

From Table 2 it is observed that the oxygen content of de-inking sludge pyrolysis oil (10-11\%) is much lower than fast pyrolysis oil obtained from traditional biomass feedstocks such as wood or straw (typically 30-50\%). Lower oxygen content increases the calorific value and stability of the oil.

A sample of each of the oils obtained from both the $\mathrm{KC}$ and AN pyrolysis runs was dissolved in an ethanol solvent and further tested using liquid GC-MS; the top 11 most abundant chromatograph peaks were identified. The chromatographs of each GC-MS run are presented in Figures 9 and 10.

From Figures 9 and 10 it is observed that the peaks obtained from both $\mathrm{KC}$ oil and AN oil are very similar. Both of these oils are comprised of mainly phenolic compounds, which explains the very low oxygen content and high carbon content of the oils observed in Table 2. The major peaks detected were also found to be consistent with that found from the work of Lou .R et al [6].

Both $\mathrm{KC}$ and AN oils also contain fatty acid methyl esters which is the major component of biodiesel. On the basis of this these oils were tested for miscibility with biodiesel, with a view to potential application as a blended fuel in modified and conventional diesel engines, and were found to be fully miscible. Different blends were then tested in a lister diesel engine, and were found to work well at lower bio-oil proportions ( $<30 \mathrm{v} / \mathrm{v} \%$ bio-oil). The results of this study were presented in a later paper [12]. Analysis of the bio oil to determine its fuel properties was also carried out, with the results shown in Table 3. Table 4 shows the ICP metals present within the oils.

Table 3 shows that bio oil obtained from de-inking sludge contains a lower water content than fast pyrolysis oil from traditional biomass feedstocks, which will lead to improved combustion characteristics. Furthermore the viscosity of the oil as well as the total acid number is significantly less than for biomass fast pyrolysis oils which results in improved flow characteristics as well as making the fuel less corrosive to equipment component parts. From Table 4 it is observed that the metals present within the oils are extremely low with Si being the highest fraction measured and this equated to 160 and $522 \mathrm{ppm}$ for $\mathrm{KC}$ and $\mathrm{AN}$ oils respectively.

\subsubsection{Intermediate Pyrolysis Permanent Gas Compositions}

Gas analysis using a GC-TCD analyser was performed on the permanent gases formed, and the normalised gas compositions along with the calorific value were subsequently determined. The gas was composed of mainly $\mathrm{CO}_{2}$ and $\mathrm{CO}$ and contained a gross heating value of between $5-6 \mathrm{MJ} / \mathrm{Nm}^{3}$, results are presented in Table 5.

\subsubsection{Intermediate Pyrolysis Solid Residue Characterisation}

The residual solids from the pyrolysis trials were mostly inert with a majority being calcium carbonate. They were characterised for elemental composition and energy content. The results revealed that full organic decomposition did not occur during pyrolysis, some residual carbon and hydrogen remained in the solids and this subsequently resulted in a residual gross heating value of the solids of between 3-5 MJ/Kg, results are presented in Table 6. 
A typical mass balance of this process at steady state produces approximately $9 \mathrm{wt} \%$ condensable organic vapours (pyrolysis oil), $1 \mathrm{wt} \%$ aqueous phase, $15 \mathrm{wt} \%$ permanent gases with the remaining $75 \mathrm{wt} \%$ being the solid inert residues, mainly calcium based. An implementation study is now being carried out to analyse how this process would integrate into a typical mill and the associated economic impact, but initial indications are that considerable savings could be made, particularly from the reduced or eliminated use of natural gas for co-firing de-inking sludge. The opportunity exists to sell an alkaline ash to the construction industry or for use as animal bedding. The possibilities of using the ash product as a catalyst are also being explored. One configuration for the implementation of a pyrolysis system for CHP generation at paper making sites is shown in Figure 11.

At full scale it would not be necessary to pelletise the feed, although drying is still necessary. A full-scale system based on this technology could process up to 20,000 dry tonnes per year and multiple units in parallel are possible for higher tonnages.

\subsection{CONCLUSIONS}

Secondary fibre paper mills that utilise de-inking processes for the manufacture of new paper sheets have the potential to generate large quantities of de-inking sludge waste which is currently either disposed of by landfill, landspread or incineration, and these practices are unsustainable.

This work has developed a method to utilise de-inking sludge waste fractions for the on-site production of combined heat and power (CHP) using the advanced thermal conversion method known as intermediate pyrolysis. The pyrolysis oil produced contained a gross heating value of $36-37 \mathrm{MJ} / \mathrm{kg}$ and was composed of mainly phenolic compounds and fatty acid methyl esters. The oil produced was found to have improved fuel physical properties when compared to traditional pyrolysis oil produced from the fast pyrolysis of biomass, and was comparable to biodiesel. The main attraction of this process is that it can remove the need for paper mills to import large quantities of natural gas to cofire sludge in a combustion unit. At full scale it is envisaged that the solids formed from the pyrolysis of de-inking sludge would be co-fired with the hot pyrolysis vapours which are formed from the process in a combustion unit downstream. The ash product formed could then be sold to cement industries as cement or concrete admixture. Some of the hot exhaust gases from the combustion unit would be required to run the drying and pyrolysis process itself with the majority of exhaust gases being routed to either a gas turbine or boiler for electricity generation. Processing de-inking sludge in this way would significantly reduce the natural gas requirement of mills that currently combust there sludge using natural gas, and this is overall a sustainable solution which would significantly reduce this waste fraction whilst simultaneously generating useful CHP energy at paper making sites.

\subsection{ACKNOWLEGMENTS}

The authors would like to thank the Engineering and Physical Science Research Council (EPSRC), Aylesford Newsprint, Smurfit Kappa SSK and Kimberly-Clark Flint for sponsoring the project. The authors would also like to thank Muhammad Saghir of the European Bioenergy Research Institute for his technical support during the work; all their contributions are greatly acknowledged.

\subsection{REFERENCES}

[1] Ouadi .M, Brammer .G.J, Hornung .A, 2011, Sustainable energy from paper industry wastes, IN Bridgwater A.V (eds.) Proceedings of the bioten conference on biomass bioenergy and biofuels 2010 , Berkshire, CPL Press, 267-278

[2] Ouadi .M, Brammer .G.J, Kay .M, Hornung .A, 2011, Waste to Power, Tappi .J; 11(2); 55-64 
[3] Dunster .M.A, 2007, Characterisation of Mineral Wastes, Resources and Processing technologies - Integrated waste management for the production of construction material, http://www.smartwaste.co.uk/filelibrary/Portland_cement_paper_sludge.pdf [Accessed 21.10.11]

[4] Kay M. The Power of Waste. Tappi J 2007; 49, 2, 21-22.

[5] CANMET Energy Technology Centre; 2005; Pulp and paper sludge to energy-preliminary assessment of technologies Canada, 48-77

[6] Lou .R et al, 2011, Energy and resource utilization of de-inking sludge pyrolysis, Applied Energy, [Article in Press]

[7] Hornung, A. et al, 2009; The thermal treatment of biomass, Great Britain Patent Application Number: GB 0808739.7: Application submitted: May 15, 2009. World Patent Applied for (WO 2009/138757; November 19, 2009).

[8] Channiwala S.A, Parikh P.P, 2002, A unified correlation for estimating HHV of solid liquid and gaseous fuels, Fuel,81,1051-63

[9] Hong .T, Shu-rong.W, 2009, Experimental study of the effects of acid washing pretreatment on biomass pyrolysis, J Fuel Chem Technol, 37, 6, 668-672

[10] Piyali D, Ganesh A, Wangikar P. Influence of pretreatment for deashing of sugarcane bagasse on pyrolysis products. Biomass and Bioenergy, 2004, 27(5): 445-457.

[11] Wang S R, Liao Y F, Liu Q, Luo Z Y, Cen K F. Experimental study of the influence of acid wash on cellulose pyrolysis. J Fuel Chem Technol, 2006, 34(2): 179-183.

[12] Hossain .K .A, Ouadi .M, Siddiqui .S, Yang .Y, Brammer .J, Hornung .A, Kay .M, Davies .P.A., 2012, Experimental investigation of performance, emission and combustion characteristics of an indirect injection (IDI) multi-cylinder CI engine fuelled by blends of de-inking sludge pyrolysis oil with biodiesel, Fuel, [Article in Press Accepted] 
Figure(s)

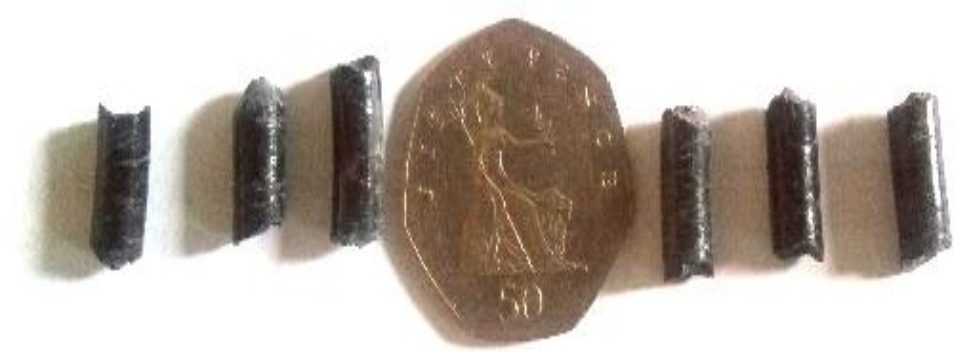

Figure 1 Aylesford Newsprint (AN) dried de-inking sludge pellets 


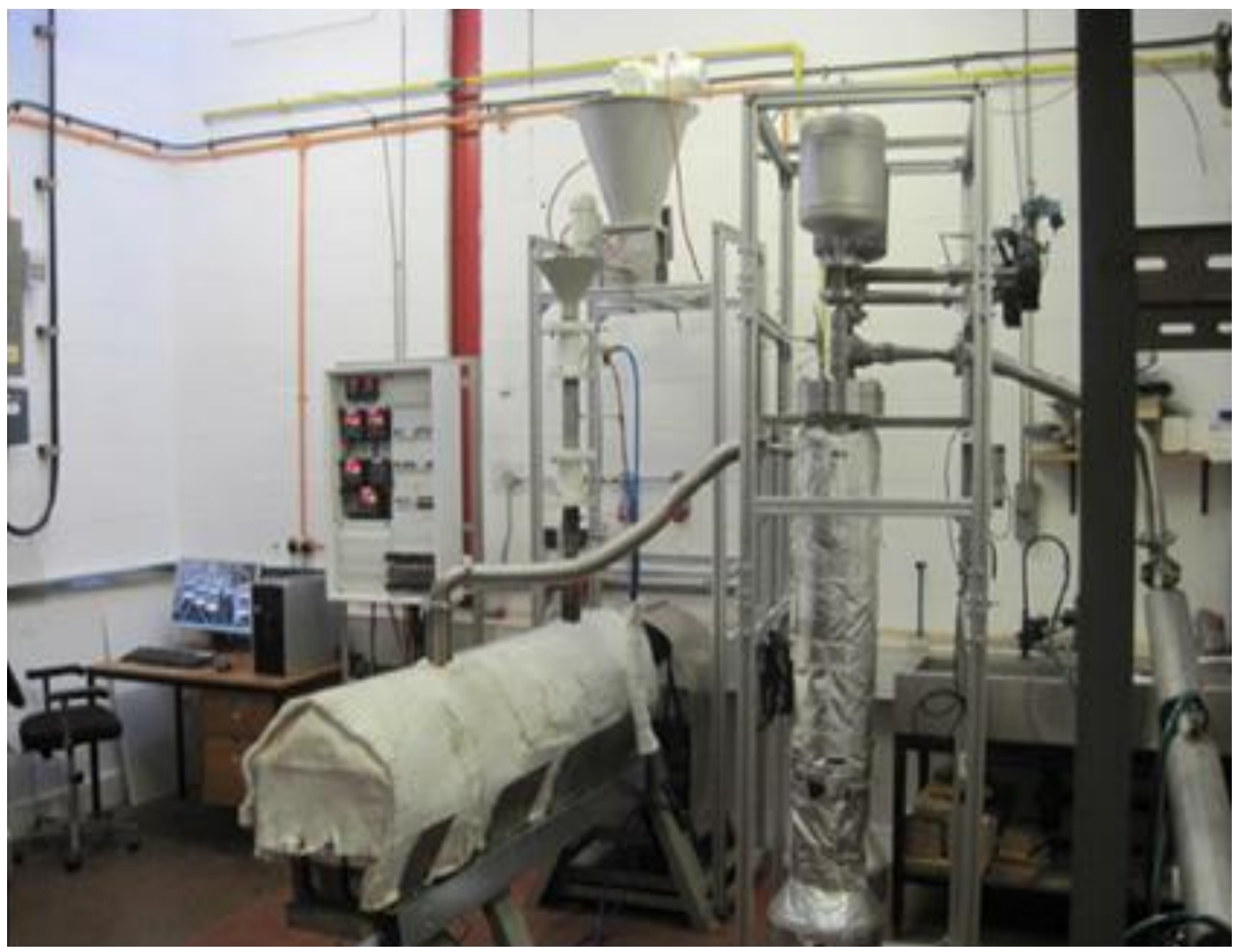

Figure 2 Pyroformer intermediate pyrolysis system Aston University 


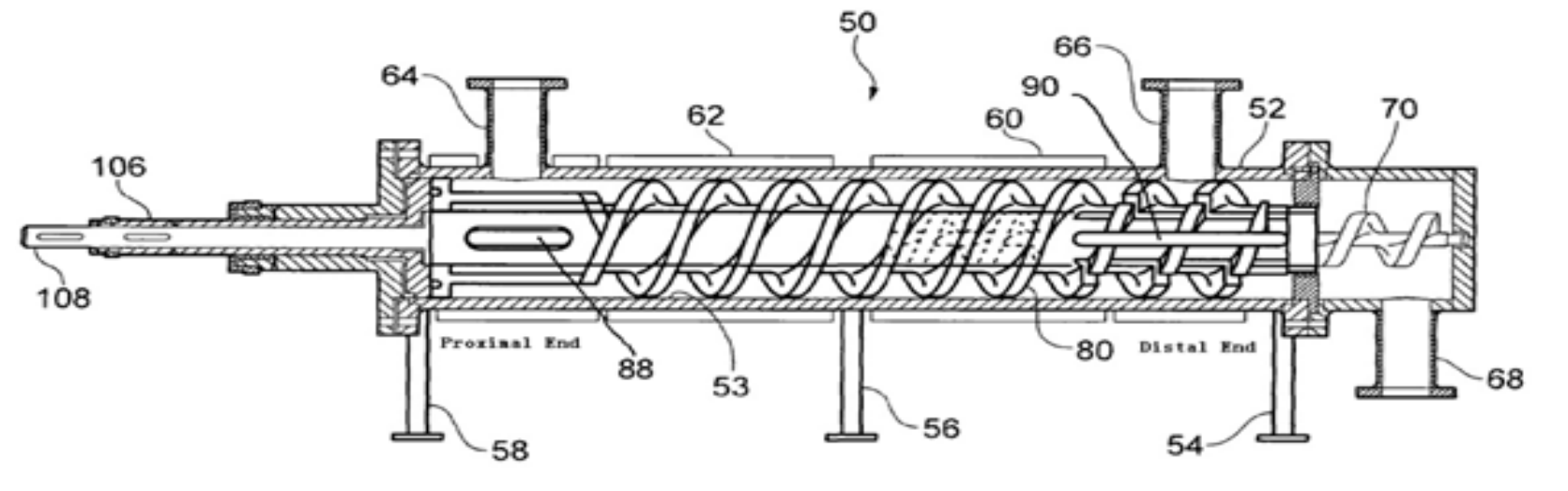

106 External Screw Shaft, 108 Internal Screw Shaft, 64 Feed Inlet Pipe, 62,60,52,50 Electrical Heating Bands, 58,56,54 Supports, 88 External Screw Slot, 90 External Screw Slot, 80 External Screw, 70 Internal Screw, 68 Solid Drop Out Pipe, 66 Gas Outlet Pipe

Figure 3 Internal mechanics of the Pyroformer reactor 


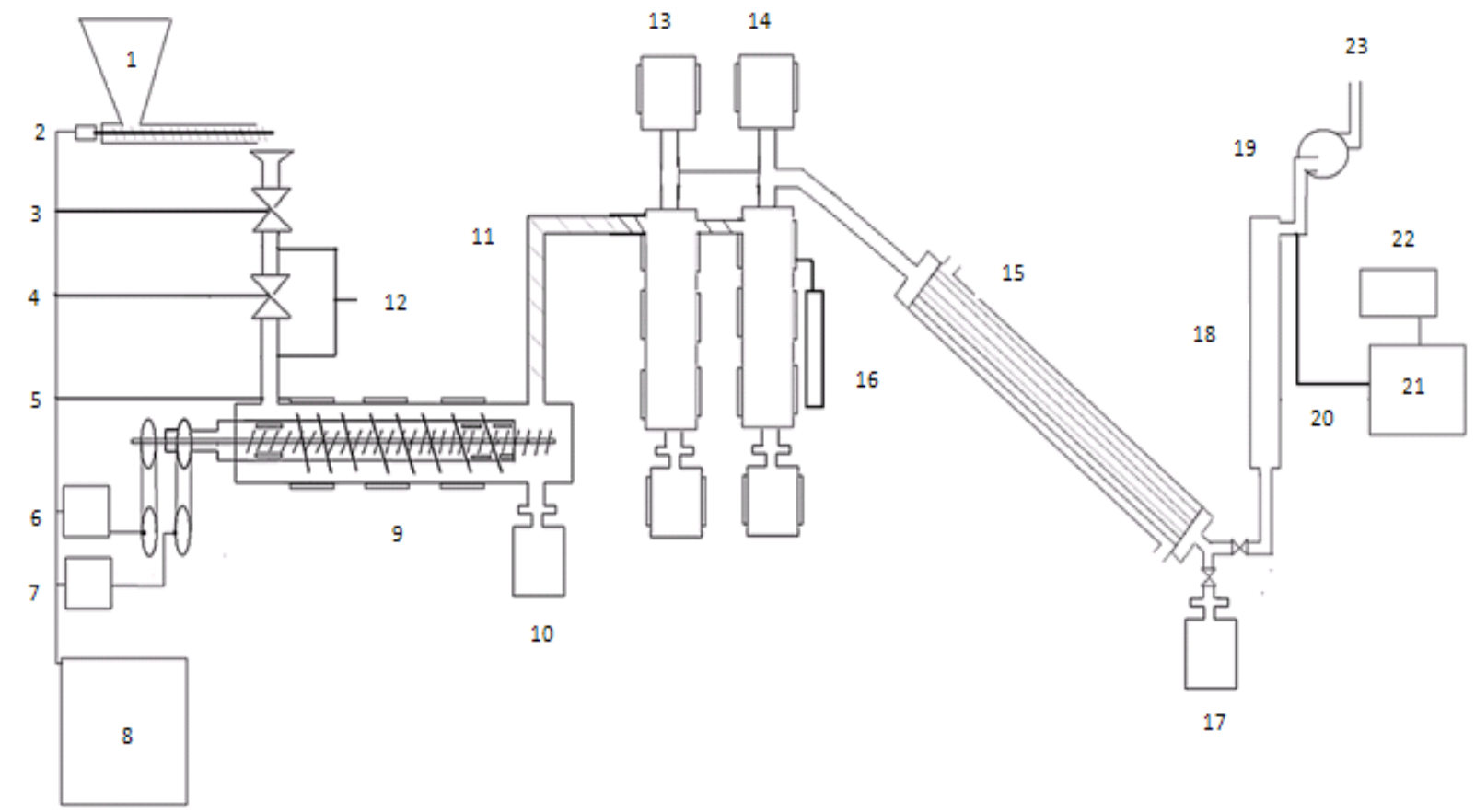

1 Feed Hopper, 2 Auger, 3 Actuating Value, 4 Actuating Valve, 5 Electric Heating Bands, 6 Electric Motor, 7 Electric Motor, 8 Main Control Board, 9 Pyrolysis Reactor, 10 Char Collection Vessel, 11 Heated Line, $12 \mathrm{~N}_{2}$ Purge Line, 13 Heated Filter Candle, 14 Heated Filter Candle, 15 Shell and Tube Condenser, 16 Filter Candle Control Board, 17 Pyrolysis Oil Collection Vessel, 18 Electrostatic Precipitator, 19 Gas Suction Pump, 20 Gas Sampling Line, 21 Gas Chromatograph, 22 Computer, 23 Extraction Vent

Figure 4 Schematic diagram of the intermediate pyrolysis system 


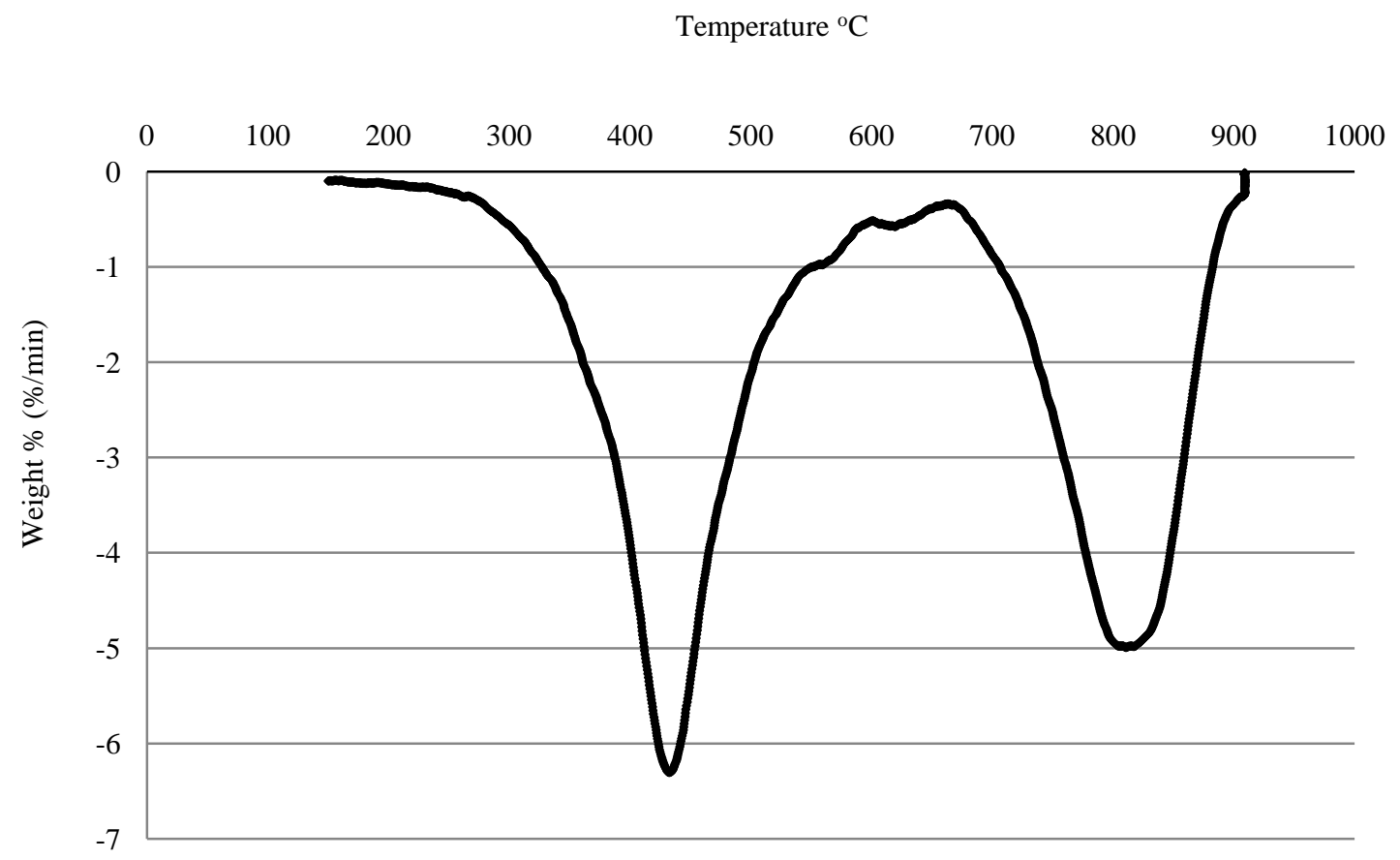

Figure 5 (KC) De-inking sludge: TGA pyrolysis derivative weight loss profile 


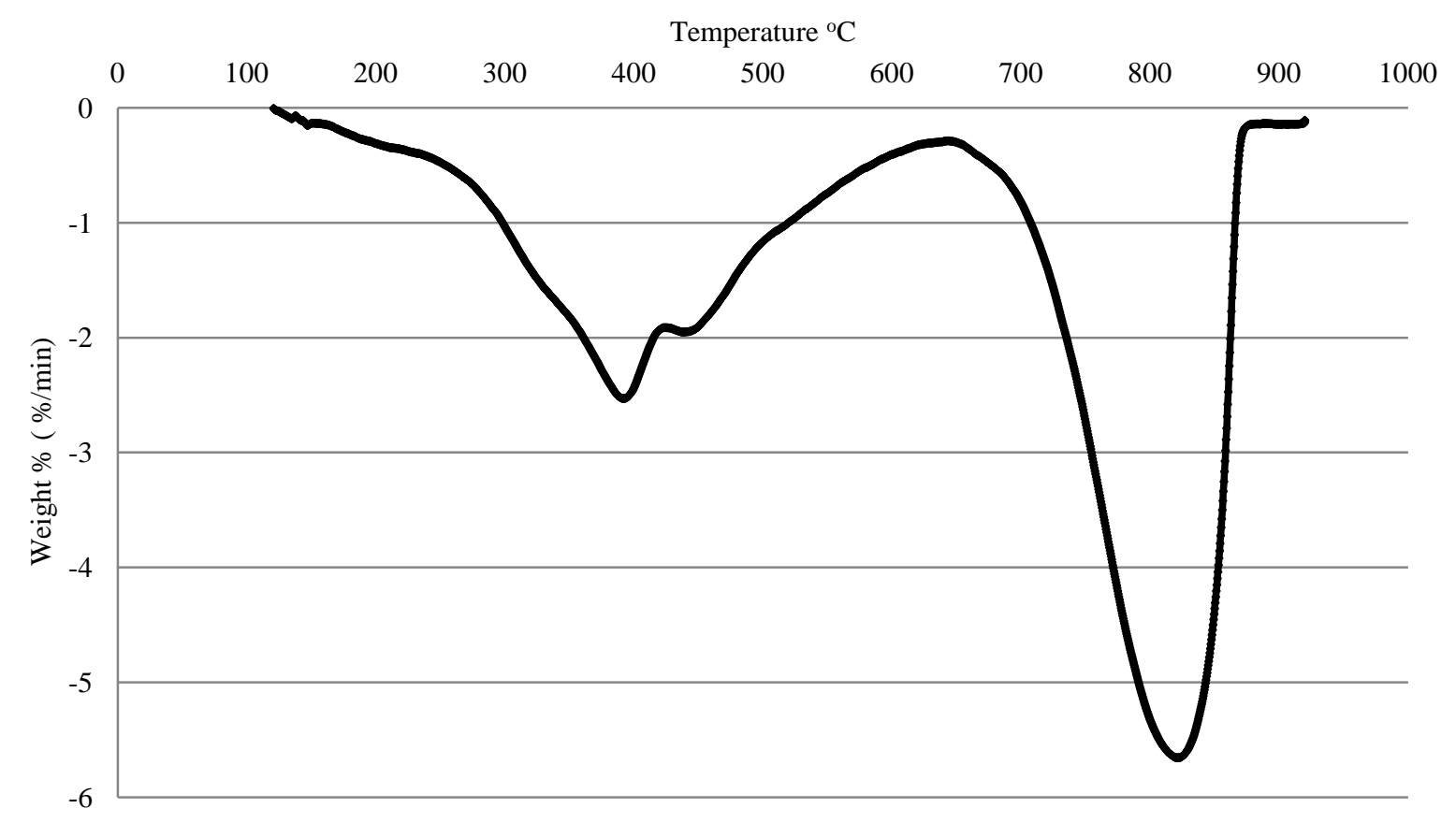

Figure 6 (AN) De-inking sludge: TGA pyrolysis derivative weight loss profile 
Temperature ${ }^{\circ} \mathrm{C}$

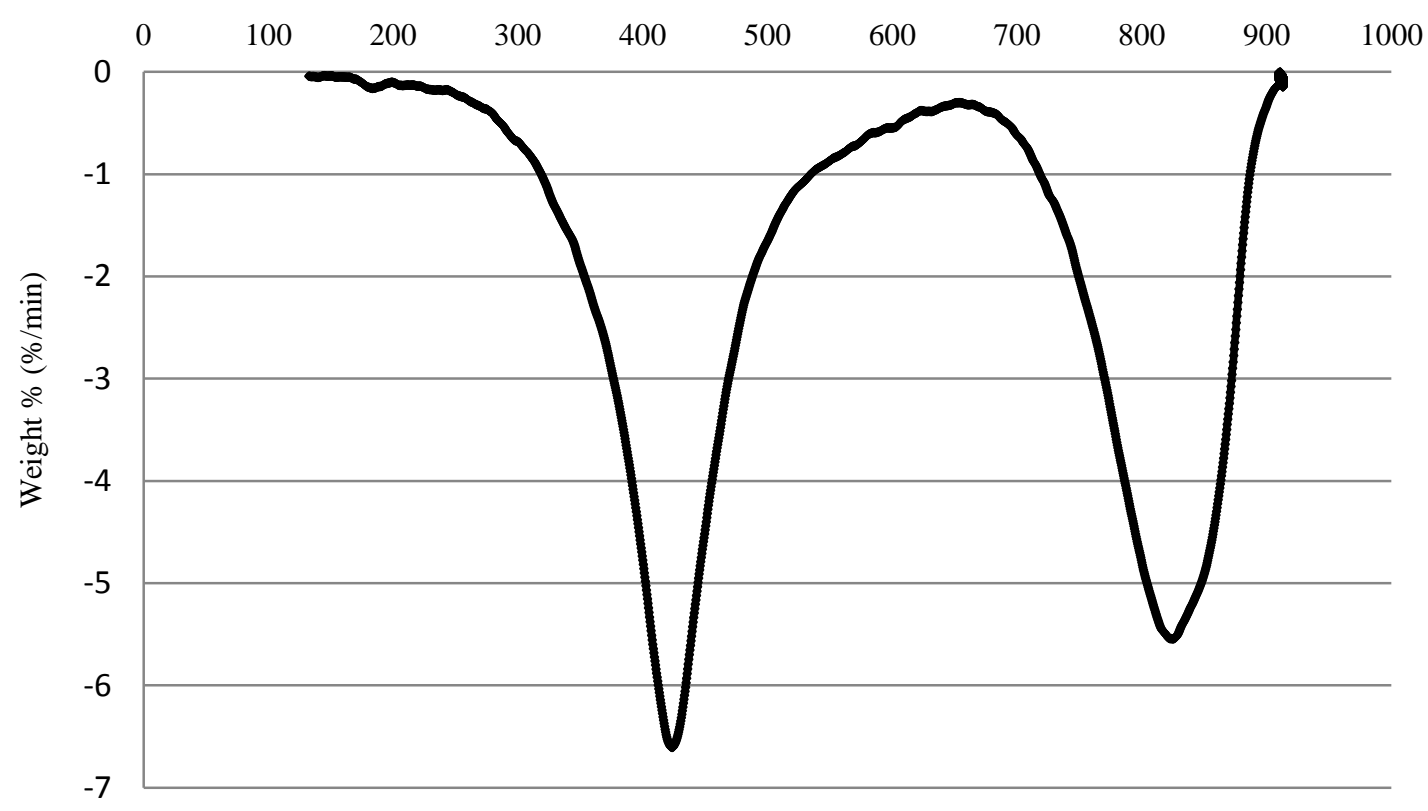

Figure 7 (KC) De-inking sludge: TGA combustion derivative weight loss profile 


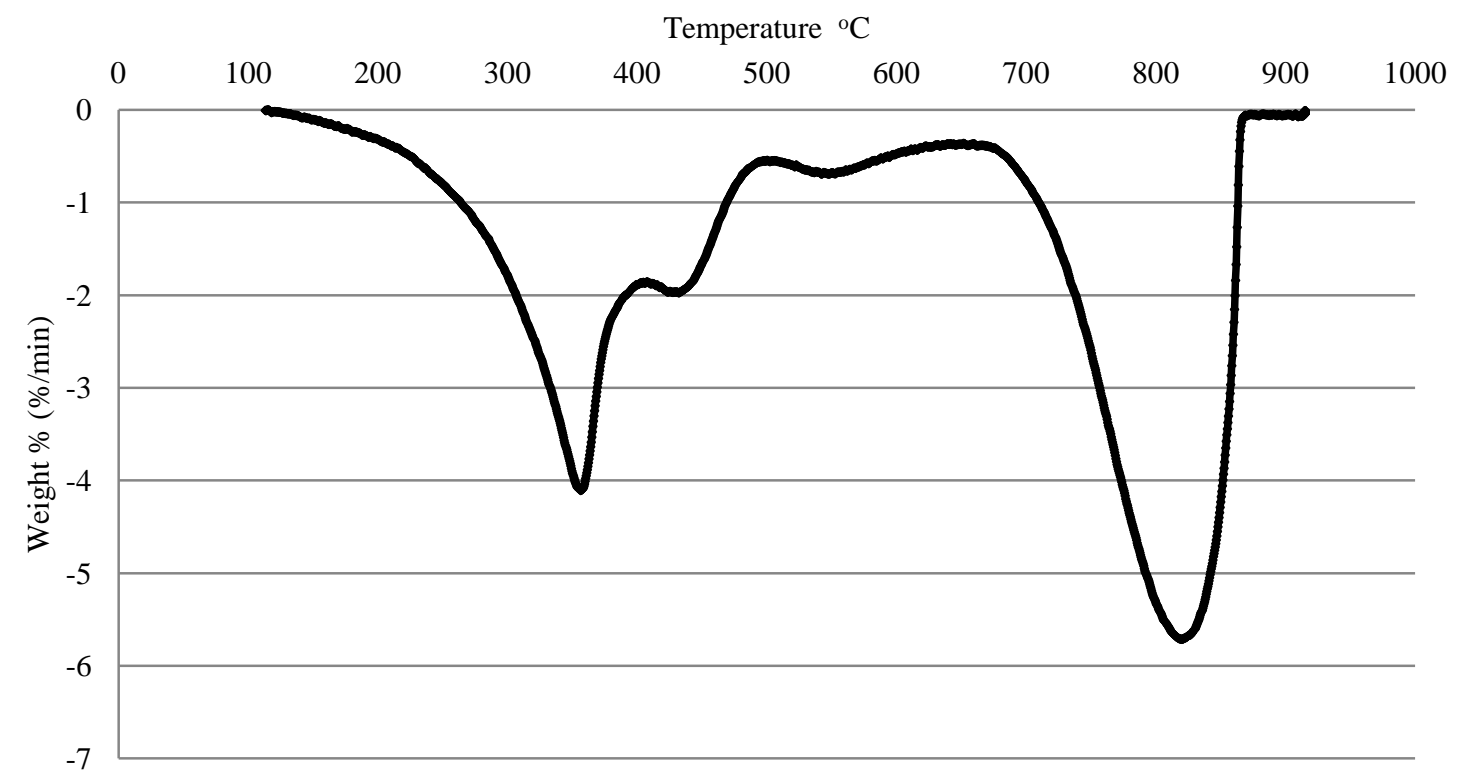

Figure 8 (AN) De-inking sludge: TGA combustion derivative weight loss profile 


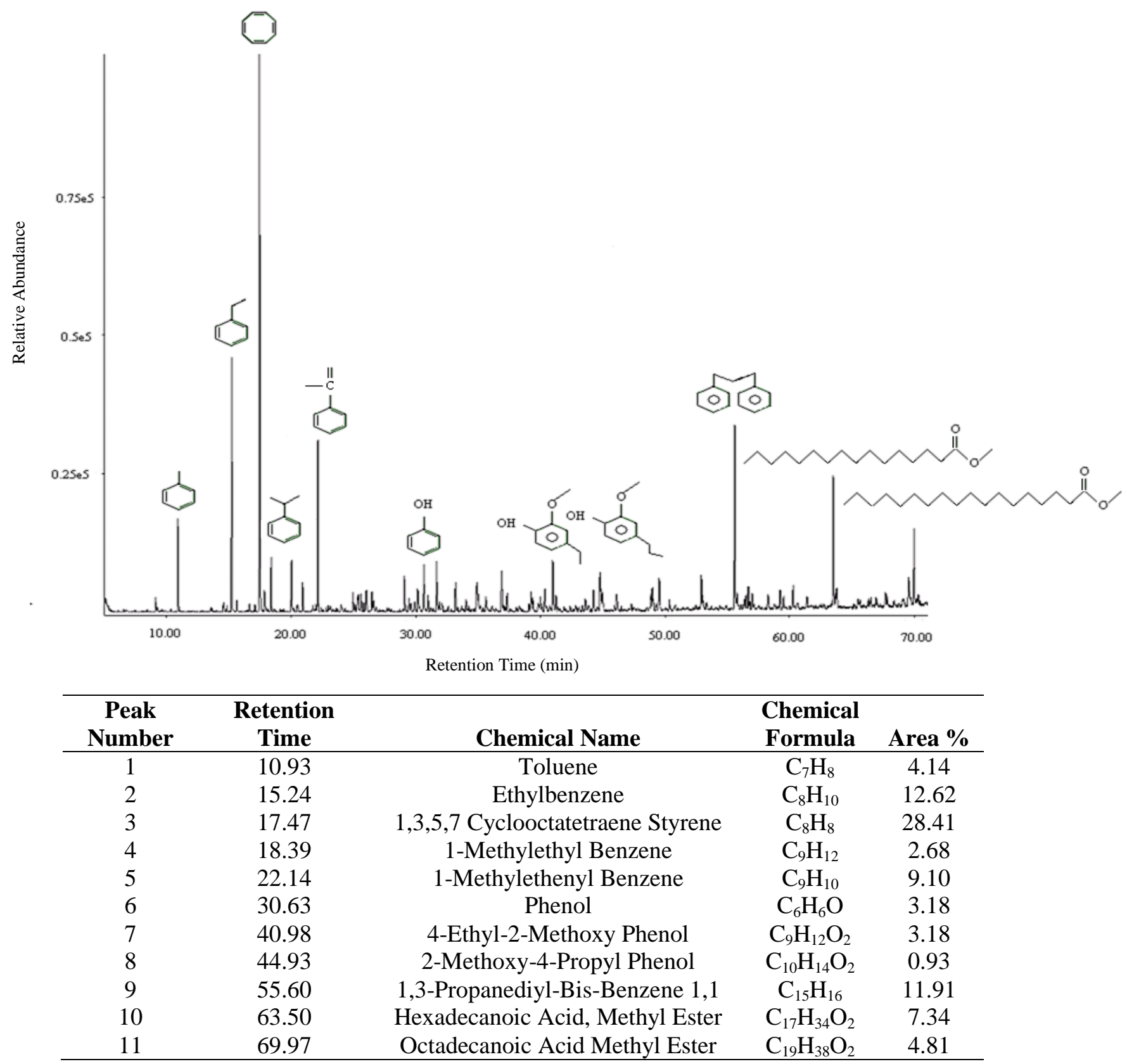

Figure 9 Liquid GC-MS chromatograph of (AN) de-inking sludge bio-oil 


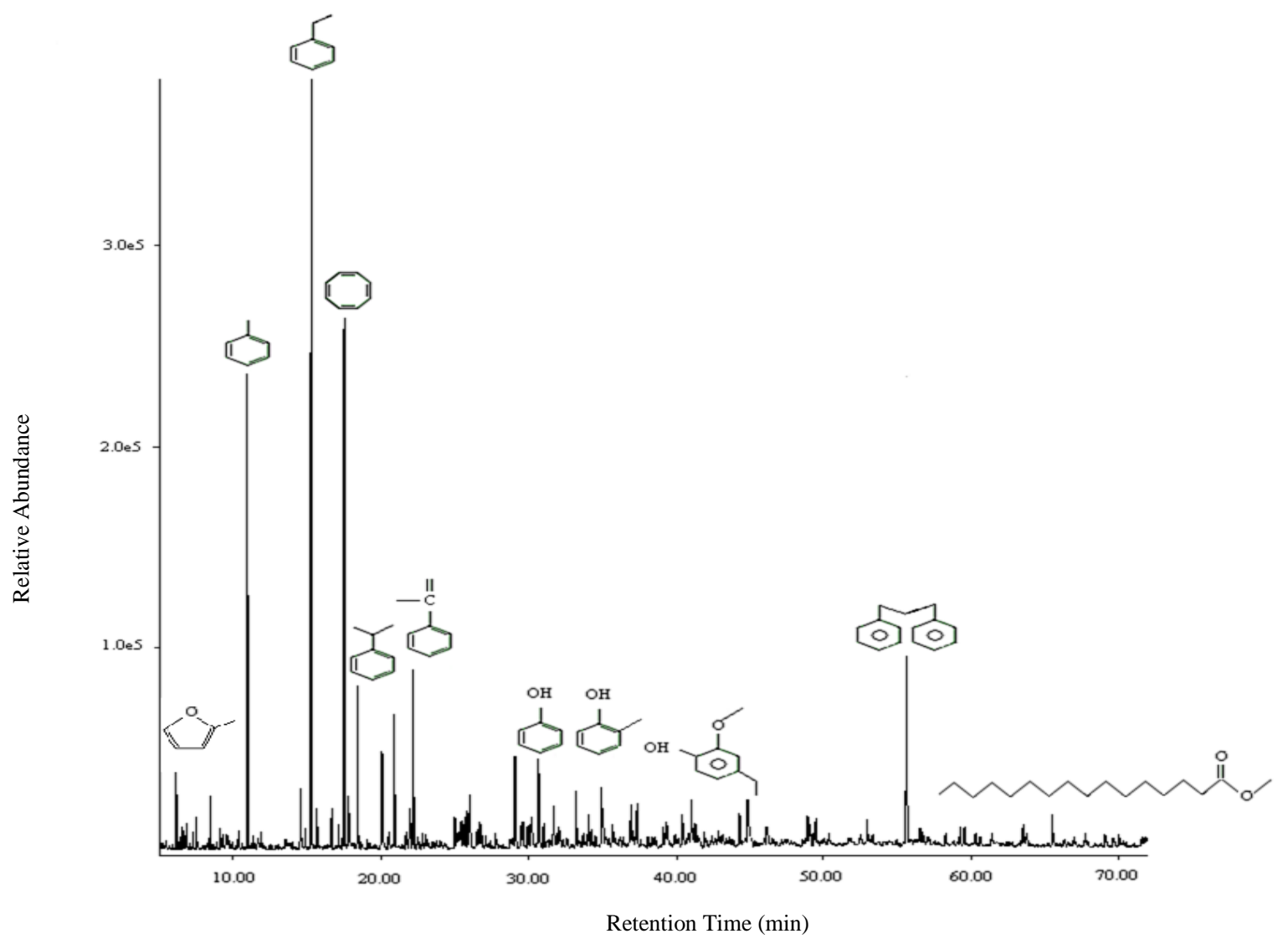

\begin{tabular}{ccccc}
\hline $\begin{array}{c}\text { Peak } \\
\text { Number }\end{array}$ & $\begin{array}{c}\text { Retention } \\
\text { Time }\end{array}$ & Chemical Name & $\begin{array}{c}\text { Chemical } \\
\text { Formula }\end{array}$ & Area \% \\
\hline 1 & 6.16 & 2-Methyl-Furan & $\mathrm{C}_{5} \mathrm{H}_{6} \mathrm{O}$ & 1.56 \\
2 & 10.96 & Toluene & $\mathrm{C}_{7} \mathrm{H}_{8}$ & 12.35 \\
3 & 15.28 & Ethylbenzene & $\mathrm{C}_{8} \mathrm{H}_{10}$ & 22.99 \\
4 & 17.51 & 1,3,5,7 Cyclooctatetraene Styrene & $\mathrm{C}_{8} \mathrm{H}_{8}$ & 15.67 \\
5 & 18.43 & 1-Methylethyl Benzene & $\mathrm{C}_{9} \mathrm{H}_{12}$ & 4.47 \\
6 & 22.18 & 1-Methylethenyl Benzene & $\mathrm{C}_{9} \mathrm{H}_{10}$ & 5.50 \\
7 & 30.63 & Phenol & $\mathrm{C}_{6} \mathrm{H}_{6} \mathrm{O}$ & 3.94 \\
8 & 33.19 & 2-Methyl Phenol & $\mathrm{C}_{7} \mathrm{H}_{8} \mathrm{O}$ & 1.83 \\
9 & 41.00 & 4-Ethyl-2-Methoxy Phenol & $\mathrm{C}_{9} \mathrm{H}_{12} \mathrm{O}_{2}$ & 2.00 \\
10 & 55.60 & 1,3-Propanediyl-Bis-Benzene1,1 & $\mathrm{C}_{15} \mathrm{H}_{16}$ & 7.56 \\
11 & 63.50 & Hexadecanoic Acid, Methyl Ester & $\mathrm{C}_{17} \mathrm{H}_{34} \mathrm{O}_{2}$ & 0.73 \\
\hline
\end{tabular}

Figure 10 Liquid GC-MS chromatograph of (KC) de-inking sludge bio-oil 


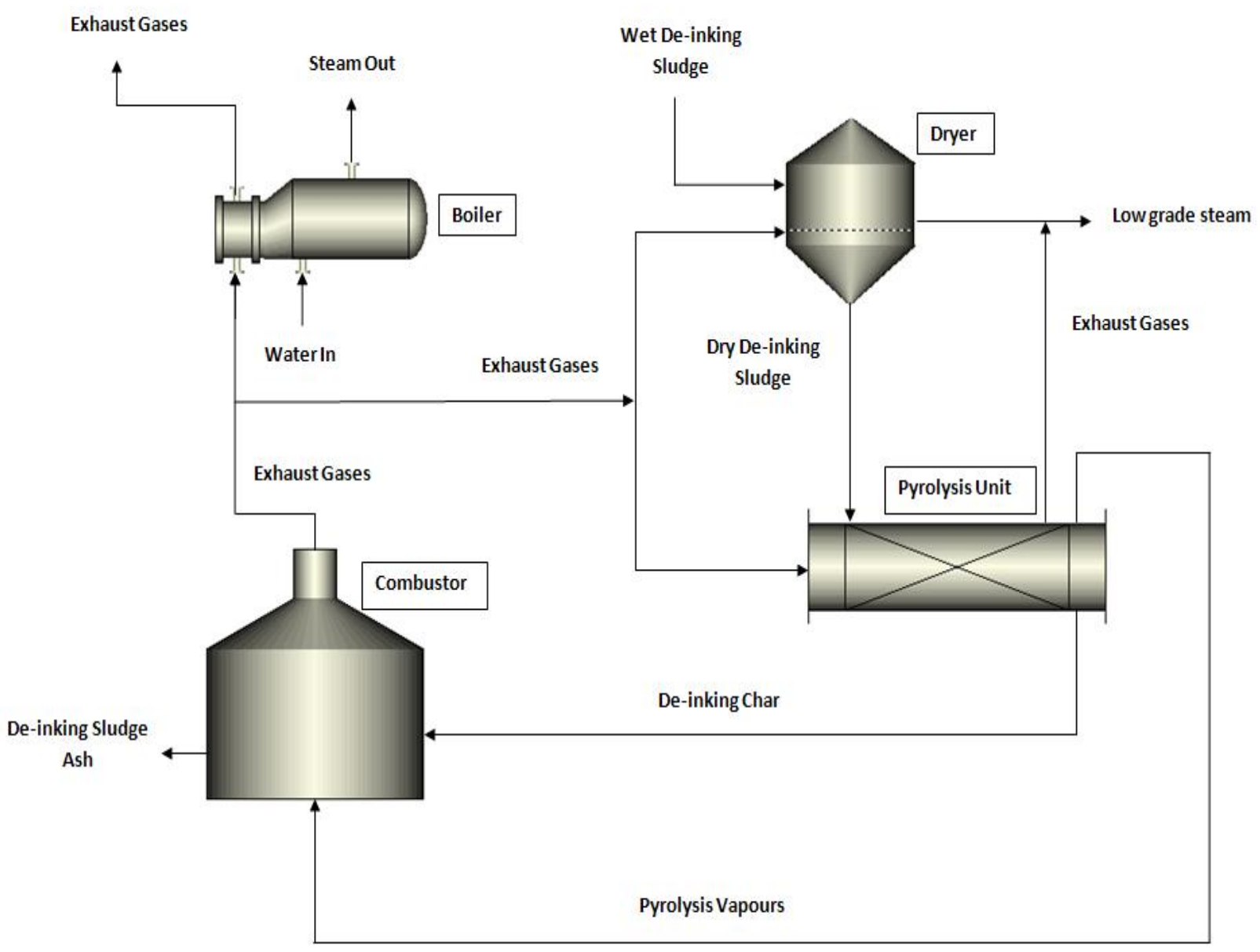

Figure 11 Proposed de-inking sludge pyrolysis process 


\begin{tabular}{lcc}
\hline & $\begin{array}{c}\text { Aylesford Newsprint (AN) } \\
\text { De-inking Sludge }\end{array}$ & $\begin{array}{c}\text { Kimberly-Clark (KC) } \\
\text { De-inking Sludge }\end{array}$ \\
\hline $\begin{array}{lcc}\text { Proximate Analysis wt\% } \\
\text { (dry basis) }\end{array}$ & \\
Moisture & 1 & 1.3 \\
Volatiles & 46.3 & 55.1 \\
Fixed Carbon & 1.1 & $<0.1$ \\
Ash & 51.6 & 43.6 \\
Gross HV (MJ/Kg) & 6.4 & 7.0 \\
Ultimate Analysis wt\% & & \\
(dry basis) & & \\
Carbon & 21.1 & 21.7 \\
Hydrogen & 2.3 & 2.8 \\
Oxygen* & 24.7 & 29.8 \\
Nitrogen & 0.3 & 2.1 \\
Sulphur & $<0.1$ & $<0.1$ \\
Chlorine & $<0.1$ & $<0.1$ \\
\hline
\end{tabular}

* Obtained by difference

Table 1 Proximate, ultimate analysis and heating values of de-inking sludge 


\begin{tabular}{lcc}
\hline & $\begin{array}{c}\text { Aylesford Newsprint (AN) } \\
\text { De-inking Sludge } \\
\text { Bio-oil } \\
\text { Result wt\% }\end{array}$ & $\begin{array}{c}\text { Kimberly-Clark (KC) } \\
\text { De-inking Sludge } \\
\text { Bio-oil } \\
\text { Result wt\% }\end{array}$ \\
\hline Carbon & 78.71 & 76.58 \\
Hydrogen & 10.08 & 8.38 \\
Nitrogen & 1.02 & 1.86 \\
Sulphur & 0.55 & 0.58 \\
Oxygen & 10.08 & 11.27 \\
Ash & $<0.02$ & $<0.02$ \\
\hline Gross heating value $(\mathrm{MJ} / \mathrm{Kg})$ & 37 & 36 \\
\hline
\end{tabular}

Table 2 Ultimate analysis and gross heating values of (AN) and (KC) de-inking sludge bio oil 


\begin{tabular}{lccc}
\hline Units & $\begin{array}{c}\text { Aylesford Newsprint (AN) } \\
\text { De-inking Sludge } \\
\text { Bio-oil } \\
\text { Result wt\% }\end{array}$ & $\begin{array}{c}\text { Kimberly-Clark (KC) } \\
\text { De-inking Sludge } \\
\text { Bio-oil } \\
\text { Result wt\% }\end{array}$ \\
\hline Water Content & $\%$ & 4 & 3 \\
$\mathrm{pH}$ & - & 4.8 & 4.7 \\
Flash Point & ${ }^{\circ} \mathrm{C}$ & 168 & 160 \\
Density & $\mathrm{Kg} / \mathrm{m}^{3}$ & 980 & 984 \\
Cetane Index & - & $\mathrm{n} / \mathrm{a}$ & 23 \\
Kinematic Viscosity @ $40^{\circ} \mathrm{C}$ & $\mathrm{cSt}$ & 12.3 & 9 \\
Total Acid Number & $\mathrm{mgKOH} / \mathrm{g}$ & 26.0 & 32.8 \\
Copper Corrosion & - & $3 \mathrm{~A}$ & $2 \mathrm{C}$ \\
Carbon Residue & $\mathrm{Wt} \%$ & 3.9 & 4.6 \\
\hline
\end{tabular}

Table 3 (AN) and (KC) de-inking sludge bio oil fuel properties 


\begin{tabular}{ccc}
\hline Metal & $\begin{array}{c}\text { Aylesford Newsprint (AN) de-inking } \\
\text { sludge bio oil } \\
\text { (ppm) }\end{array}$ & $\begin{array}{c}\text { Kimberly Clark (KC) de-inking } \\
\text { sludge bio oil } \\
\text { (ppm) }\end{array}$ \\
\hline $\mathrm{P}$ & 91 & 5 \\
$\mathrm{Sn}$ & $<1$ & $<1$ \\
$\mathrm{Mo}$ & 1 & 1 \\
$\mathrm{~B}$ & 6 & 1 \\
$\mathrm{Zn}$ & 53 & 16 \\
$\mathrm{~Pb}$ & 2 & 1 \\
$\mathrm{Cd}$ & $<1$ & $\mathrm{n} / \mathrm{a}$ \\
$\mathrm{Ni}$ & $<1$ & 5 \\
$\mathrm{Ba}$ & 21 & 1 \\
$\mathrm{Mn}$ & 1 & $<1$ \\
$\mathrm{Fe}$ & 4 & 1 \\
$\mathrm{Cr}$ & 1 & $<1$ \\
$\mathrm{Si}$ & 522 & 160 \\
$\mathrm{Al}$ & 3 & $<1$ \\
$\mathrm{~V}$ & $<1$ & $<1$ \\
$\mathrm{Ca}$ & 69 & 10 \\
$\mathrm{Cu}$ & 3 & $<1$ \\
$\mathrm{Ti}$ & $<1$ & $<1$ \\
$\mathrm{Na}$ & 12 & 1 \\
$\mathrm{Mg}$ & 2 & $<1$ \\
$\mathrm{Li}$ & $\mathrm{n} / \mathrm{a}$ & $<1$ \\
\hline
\end{tabular}

Table 4 (AN) and (KC) de-inking sludge bio oil metals analysis 


\begin{tabular}{lcc}
\hline $\begin{array}{l}\text { Normalised Pyrolysis } \\
\text { Gas Composition }\end{array}$ & $\begin{array}{c}\text { Aylesford Newsprint (AN) } \\
\text { De-inking Sludge } \\
(\mathbf{v} / \mathbf{v} \%)\end{array}$ & $\begin{array}{c}\text { Kimberly-Clark (KC) } \\
\text { De-inking Sludge } \\
\text { (v/v \%) }\end{array}$ \\
\hline $\mathrm{H}_{2}$ & - & 1.9 \\
$\mathrm{CO}$ & 22.7 & 25.5 \\
$\mathrm{CO}_{2}$ & 71.2 & 66.3 \\
$\mathrm{CH}_{4}$ & 6.1 & 6.3 \\
\hline Gross heating value $\left(\mathrm{MJ} / \mathrm{Nm}^{3}\right)$ & 5.5 & 6.2 \\
\hline
\end{tabular}

Table 5 Normalised pyrolysis gas composition from the pyrolysis of (AN) and (KC) de-inking sludge 


\begin{tabular}{|c|c|c|}
\hline & $\begin{array}{c}\text { Aylesford Newsprint (AN) } \\
\text { De-inking Sludge } \\
\text { Solid Residue } \\
\text { Result wt\% }\end{array}$ & $\begin{array}{c}\text { Kimberly-Clark (KC) } \\
\text { De-inking Sludge } \\
\text { Solid Residue } \\
\text { Result wt\% }\end{array}$ \\
\hline Carbon & 17.12 & 20.02 \\
\hline Hydrogen & 1.13 & 2.19 \\
\hline Nitrogen & 0.26 & 0.38 \\
\hline Sulphur & $<0.1$ & $<0.1$ \\
\hline Oxygen* & 21.49 & 23.91 \\
\hline Ash & 60 & 53.5 \\
\hline Gross heating value $(\mathrm{MJ} / \mathrm{Kg})$ & 3.3 & 4.9 \\
\hline
\end{tabular}

Table 6 Pyrolysis de-inking sludge solid residue ultimate characterisation and energy content 


\section{List of Potential Reviewers}

\section{Professor Jim Swithenbank}

Chemical Engineering

Sheffield University

Email: j.swithenbank@sheffield.ac.uk

\section{Professor Paul Williams}

Leeds University

Environmental Engineering

Email: p.t.williams@leeds.ac.uk

\section{Professor Galip Akay}

Newcastle University

Chemical Engineering

Email: galip.akay@newcastle.ac.uk 